\title{
Climate change expert stirs new controversy
}

Paul Smaglik, Washington

Opponents of the Kyoto Protocol on climate change have found fresh ammunition in the shape of a new scientific paper. The controversial article suggests that gases other than carbon dioxide are mainly to blame for the rapid global warming seen over the past few decades.

The Kyoto Protocol aims to reduce global warming by cutting $\mathrm{CO}_{2}$ emissions, mainly from the use of fossil fuels. But the paper, from a team led by James Hansen of the Goddard Institute for Space Studies in New York, proposes that reducing emissions of methane, soot and the gases that cause photochemical smogs would be the easiest way to limit climate change in the short term.

Other climatologists have questioned the assumptions on which Hansen's conclusions are based, and note that the paper, published last week in Proceedings of the National Academy of Sciences (97, 9875-9880; 2000), has not been subjected to formal peer review.

Hansen helped alert the world to global warming in 1988, warning the US Congress: "It is time to stop waffling... the greenhouse effect is here." Not surprisingly, his latest work has been greeted with glee by the Global Climate Coalition, a Washington-based industry body that is lobbying against US ratification of the Kyoto Protocol. Its website concludes that "too much emphasis has been placed on the effects of burning fossil fuels".

Hansen's modelling assumes that levels of $\mathrm{CO}_{2}$ in the atmosphere will continue to increase at a rate of 1.5 parts per million per year. He also calculates that tiny particles entering the atmosphere as a result of fossilfuel burning - in particular aerosols of sulphates - have a cooling effect that is largely counterbalancing the warming caused by $\mathrm{CO}_{2}$. Given this, Hansen argues that measures to limit global warming should focus on pollutants giving rise to ozone in the atmosphere.

But Hansen's assumptions are controversial. First, population growth and industrialization in the developing world mean that $\mathrm{CO}_{2}$ emissions could grow. "I think it's actually very difficult to keep $\mathrm{CO}_{2}$ growth rates to Hansen's targets," says Tom Wigley of the National Center for Atmospheric Research in Boulder, Colorado.

Second, huge uncertainty surrounds the size of the cooling effects of sulphates and other aerosols (see News Feature, pages 10-12). Most climatologists say that, in the absence of better data, we cannot assume that aerosols will offset the warming influence of $\mathrm{CO}_{2}$.

Hansen argues that population growth and industrialization do not pose insurmountable problems. He says that renewable energy, and policies encouraging energy

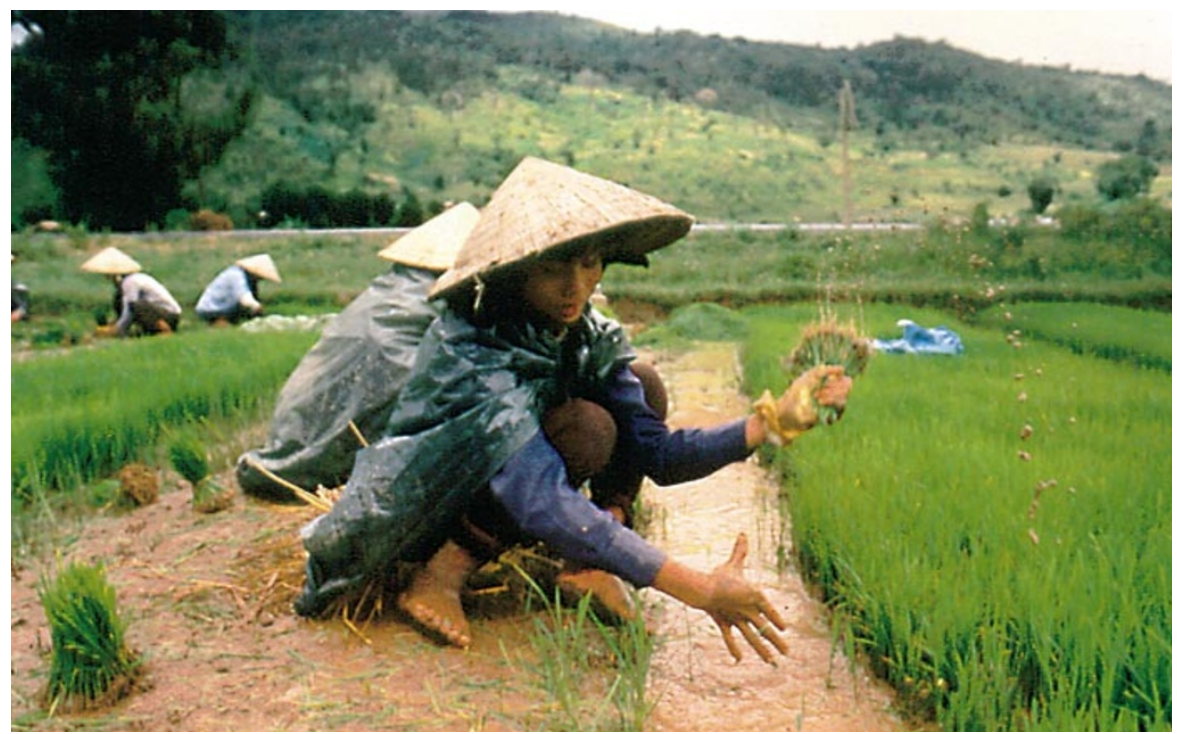

Heating up: would reducing the methane emitted by rice fields make an impact on global warming?

efficiency, could help meet his predictions.

Michael MacCracken, director of the National Assessment Coordination Office of the US Global Change Research Program, agrees that targeting methane and soot could help stem global warming — at least in the short term. But he takes issue with Hansen's assumptions about fossil-fuel burning. Measures to clean up industrial emissions by removing sulphur would reduce cooling by aerosols, but leave the warming effect of $\mathrm{CO}_{2}$ unaffected, MacCracken notes.

In stressing the importance of reducing methane emissions, for which rice cultivation is a major source, and of soot, Hansen's paper also puts fresh emphasis on the need for action by developing countries. "Although the paper doesn't say so explicitly, it seems to shift the burden away from the West," says MacCracken.

But some US government advisers stress that limiting $\mathrm{CO}_{2}$ - for which the United States is the biggest polluter - remains important. "Reminding everybody that particles and non- $\mathrm{CO}_{2}$ greenhouse gases are important is fine," says John Holdren, a specialist on environmental policy at Harvard University, who chairs a panel that advises President Bill Clinton on energy issues. "But it's all too easy to get the impression from the article that $\mathrm{CO}_{2}$ is not as important as has been thought, and that is not correct."

\section{US grant glues 'virtual cell' together}

\section{Paul Smaglik, Washington}

The US National Institutes of Health (NIH)

this week launched a new series of grants for large-scale collaborative projects by pledging \$25 million over five years towards the construction of a 'virtual cell'.

The first ever 'glue grant' - so-called because it aims to link research between different institutions - has been awarded to the Alliance for Cellular Signaling (AFCS), a consortium based at the University of Texas Southwestern Medical Center and headed by Al Gilman, professor of pharmacology there.

The AFCS was formed last year to draw up a complete map of the interactions between one thousand proteins in two types of mouse cell (see Nature 402, 219; 1999). It links 50 investigators, who will provide planning and data analysis, seven laboratories devoted to conducting experiments in protein-protein interaction, and 250 'members' who will specialize in compiling protein data and posting them on websites.

The alliance will initially screen for single protein-protein interactions, then build models of complete signalling networks once every element has been characterized. "We'd really like to represent these pathways completely," says Gilman.

The five-year project will actually cost $\$ 50$ million. Gilman is raising the other half from pharmaceutical companies and nonprofit research organizations. The grant to the AFCS is one of several massive collaborative projects the NIH intends to launch during the next fiscal year that are intended to "facilitate the next evolutionary stage of integrative biomedical science". http://afcs.swmed.edu 